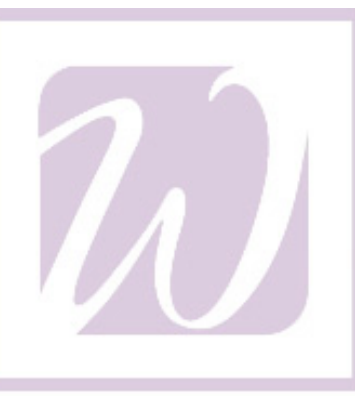

UW-WHITEWATER

\title{
Intergenerational Effects of Improving Women's Property Rights: \\ Evidence from India
}

$$
\text { By }
$$

Nayana Bose Shreyasee Das

Working Paper 17 - 01

University of Wisconsin - Whitewater

Department of Economics

4304 Hyland Hall

800 W. Main Street

Whitewater, WI 53538

Tel: (262) $472-1361$ 


\title{
Intergenerational Effects of Improving Women's Property Rights: Evidence from India
}

\author{
Nayana Bose* $\quad$ Shreyasee Das ${ }^{\dagger}$
}

This Version: November 14, 2017

First Version: November 6, 2014

\begin{abstract}
This paper analyzes the intergenerational effects following the positive changes in women's inheritance rights. The amendment to the Hindu Succession Act, the law governing inheritance for Hindus, empowered unmarried daughters at the time of the reform to have equal rights to inherit ancestral property as their brothers. We employ a difference-in-differences strategy and exploit the state level variation in a woman's exposure to the reform. Using the Indian Human Development Survey data for rural India, we find that the property rights reform significantly increased women's education. We find a significant decrease in her sons' education, the effect is magnified in households where fathers are less educated than mothers. We further explore the role of birth order and the gender composition of children to assess the intergenerational impact of this more gender equal inheritance law. Regardless of the child's gender, our results show a significant decrease in educational attainment for younger children.
\end{abstract}

JEL Codes: D13, I25, J16, K36, O12

Keywords: Property Rights, Hindu Inheritance Law, Education, Intergenerational Transfers, India

*Department of Economics, Scripps College, Claremont, CA 91711, Email: nbose@scrippscollege.edu

${ }^{\dagger}$ Department of Economics, University of Wisconsin-Whitewater, Whitewater, WI - 53190, Email: shreyasee@gmail.com. We would like to thank Aimee Chin, Rossella Calvi, Aloysius Siow, participants at the Southern Economic Association, the AIEFS, the Midwest International Economic Development conferences and at the CSWEP session on Gender Disparities at the AEA meetings for their helpful comments. All errors are our own. 


\section{Introduction}

Property and land rights play a vital role in the economic empowerment, poverty reduction, and welfare of women (Wang, 2014, Wiig, 2013). Extending this argument, the United Nations Sustainable Development Goals argue that increasing the proportion of land held by women would empower them, reduce gender inequality, and improve overall productivity. With secure property rights and greater land ownership, women can increase their income and economic contribution to the household (Deere and Doss, 2006, Duflo, 2012). Better control over income or assets also gives women greater bargaining power over household decisions regarding consumption, investment and production. Yet, gender disparity in property and inheritance rights exists in much of the developing world (Agarwal, 1994). Over the last 15 years, numerous countries have moved towards a more egalitarian system of property rights through legal changes, civil society interventions and increases in women's legal literacy programs. These changes may impact women's employment and earnings (Peterman, 2011), improve women's reproductive and sexual health and lead to better marriage market outcomes (Harari, 2016), change women's household decision-making (Mishra and Sam, 2016; Rangel, 2006, Wang, 2014) and may result in better health and education outcomes for children (Allendorf, 2007, Mishra and Sam, 2016, Rangel, 2006).

We extend this literature by analyzing an Indian inheritance rights reform that improved women's access to property. The 2005 Hindu Succession (Amendment) Act (HSAA) is a national property rights reform that entitled women to an equal share of ancestral and agricultural property as that of their brothers. However, prior to 2005, five states of Andhra Pradesh, Kerala, Karnataka, Maharashtra, and Tamil Nadu, had already pass a similar amendment to allow unmarried women to inherit ancestral property. While the amendment was a significant move towards gender equality, there is evidence of considerable bias in the actual implementation of the reform (Sircar and Pal, 2014). Women treated by the reform were no more likely to receive land than those who were not treated (Deininger, Goyal and Nagarajan, 2013, Roy, 2015). Nevertheless, post-reform, there is strong evidence 
of wealth transfer through the human capital channel. Roy (2015) and Deininger, Goyal and Nagarajan (2013) report significant increases in women's education due to the reform. Anderson and Genicot (2015) and Heath and Tan (2016) find that the HSAA increase in women's household bargaining power. However, the reform has led to more male and female suicides due to increase in domestic conflict arising from women exerting greater say in household decision making (Anderson and Genicot, 2015). The reform also inadvertently increased the costs of having daughters; Rosenblum (2015) argues that the HSAA created incentives for parents to decrease investment in their daughter's health, thus increasing the probability of female mortality. In this paper, we ask the following questions: First, do property rights reform impact a woman's well-being? Second, if women have greater control over household resources, what is the impact on her children's education? Third, do the intergenerational effects vary by position of the mother relative to the father? Lastly, we evaluate the effects in the context of the birth-order and the gender composition of children in these households.

Our paper is closest to Deininger, Goyal and Nagarajan (2013) in which the authors empirically estimate the intergenerational effects of the property rights reform through the patrilineal channel. They identify the timing of the death of the head of the household's father and note how land is bequeathed to his son (the household head) and his other children. The authors then focus on the education of the children of the household head. Our approach to the intergenerational aspect is through the channel of the mother, women (we define them as Generation I)were the direct beneficiaries of the property rights reform. We identify Generation I women's children (Generation II) and estimate their educational attainment relative to children whose mothers were not impacted by the reform. Thus, our paper differs significantly from that of Deininger, Goyal and Nagarajan (2013) since we concentrate on identifying the impact on the children of women impacted by the HSA reform, for whom this more egalitarian reform was intended.

To identify the impact of the amended Hindu Succession Law, we take advantage of the 
state-cohort variation of women's exposure to the reform. The first source of variation is the timing of a woman's marriage. Women who were unmarried at the time the reform was passed in their states form our treatment group while married women who were excluded from the benefits of the policy change are in our control group. The other source of variation comes from the states that had passed the reform before the 2005 national reform. Thus, our treatment group consists of Andhra Pradesh, Kerala, Karnataka, Tamil Nadu and Maharashtra, and the rest of the country is part of our control group. This allows us to use a difference-in-differences strategy to evaluate the causal impact of the reform. We perform a series of falsification tests to validate our empirical strategy and provide evidence that any differences in women's outcome can be attributed to the HSA amendment. Using the 200405 round of the nationally representative data, Indian Human Development Survey (IHDS), we find the reform significantly increased women's education by 0.40 and 0.50 years.

Women's education can positively shift their household bargaining power (Handa, 1996) and also plays a significant role in the intergenerational transfer of human capital (both education and health) accumulation (Currie and Moretti, 2003, Oreopoulos, Page and Stevens, 2006). To estimate how the positive impact of the HSAA for women translates to her children, we examine the age-adjusted educational attainment of children and find no significant impact. In a patriarchal society, a power imbalance between spouses may influence an empowered woman's decision-making ability. If a status conflict exists, then women who are more educated than their husbands (or earn more than them) may not be able to make a significant impact in her household. In the context of HSAA, Anderson and Genicot (2015) attribute an increase in marital discord to the changes in inheritance laws. Thus, we reassess our findings by accounting for a woman's relative position in the household. For children in reform households, with mothers more educated than fathers, there is approximately a 0.20 standard deviation significant decrease in their educational attainment. This negative result is mimicked for the sons but not for daughters in these households. Further, we find no such negative impact in households where the father is at least as educated as the mother. Thus, 
in terms of education, reform mothers who were of higher status than their husbands are not using (or are not being able to use) their empowered status to positively impact their sons through the education channel.

A growing literature has highlighted the importance of accounting for both the birthorder and sibling gender composition to explain within household differences in resource allocation among children (Black, Devereux and Salvanes, 2005; Haan, Plug and Rosero, 2014; Jayachandran and Pande, 2017; Kumar, 2016, Pande, 2003). Thus, we explore the role of both the gender composition of siblings, and the birth order of the children to further explain our results. In gender homogenous households (households that have only sons or only girls), the gap in education between siblings is not economically significant. However, we do find a significant decrease in educational attainment for the youngest children. On the other hand, the results in gender heterogenous households present slightly different patterns. In households with an older boy, there is a 0.74 standard deviation significant decrease in the younger daughter's education, however, there continues to be no significant gap between the children. Within households where boys have an older sister, we find that girls gain 0.38 standard deviation in education when compared to their younger brothers, although the overall effect on the siblings is negative. Our results show a pattern of younger children receiving lower resources towards their education.

The rest of the paper is organized as follows. Section 2 details the Hindu Succession Act and the amendments to the Act. In Section 3, we describe our empirical strategy highlighting the underlying mechanisms behind our estimations. We detail our data in Section 4 . In Section 5, we present a falsification test to test the validity of the difference-in-differences strategy and discuss our results in Section 6. We conduct some robustness checks in Section 7 and finally, we conclude in Section 8 . 


\section{Hindu Succession Act of 1956 and Amendments}

Before the Hindu Succession Act of 1956, property rights laws for Hindus were governed by two systems of doctrines, Dayabhaga, prevalent in West Bengal and Assam, and Mitakshara, prevalent in the rest of the country (Agarwal, 1994). The two systems differed in terms of how they categorized property. The Mitakshara doctrine distinguished between joint property and separate property. Joint family property includes property that has been inherited through generations patrilineally: property (such as ancestral homes and land) that has been passed from great grandfather to grandfather to father and so on. Separate property, on the other hand, is any property that is self-acquired or purchased outside of the patrilineally inherited property. Also, any asset inherited from people other than one's father or ancestors constitutes separate property (Agarwal, 1994).

The Mitakshara system specifically differentiated between these two types of properties; while sons had a birth right to joint property, women were not permitted to inherit this type property. For separate property, since the patriarch of the family had absolute control over it, he could decide how to distribute the property among his children. Under the Dayabhaga system, there was no distinction between joint and separate property, allowing the patriarch to divide the property according to his wishes. Although, all heirs, including daughters, could inherit property, preference was given to sons. It should be noted that even under the Dayabhaga system, daughters were still not able to inherit land. Thus, both systems were heavily biased against women inheriting property, especially land.

The Hindu Succession Act of 1956 (HSA), the governing inheritance laws for all Hindus ${ }^{1}$ sought to unite the two systems of inheritance and promote gender equality in property inheritance by mandating that daughters and sons were to be equal inheritors to their father's separate property. Under this law, sons were legally allowed to ask for partition of ancestral property..$^{2}$ The 1956 law specifically applies to inheritance in the case for males dying

\footnotetext{
${ }^{1}$ For the purpose of the HSA, Hindus, Buddhists, Jains and Sikhs are all viewed as Hindus. Inheritance laws in India are based on religion, Muslims and Christians have their own set of property laws.

${ }^{2}$ The HSA of 1956 applied to the entire country except for Jammu and Kashmir which has its own version
} 
intestate (without a will or settlement), which is particularly important for rural Indian households where formal wills are rarely written. ${ }^{3}$ While sons continued to be entitled to both ancestral and separate property under the $1956 \mathrm{HSA}$, the law did not give daughters the right to inherit joint property.

Over time, states started to amend the HSA of 1956 to make it more gender equal. $4^{4}$ Specifically, Kerala (in 1976), Andhra Pradesh (in 1986), Tamil Nadu (in 1989), Maharashtra and Karnataka (in 1994) had all amended the Act to allow women to have an equal share in ancestral property, as long as they were unmarried at the time of the reform. Kerala is particularly interesting, since its amendment to the HSA abolished the system of joint property altogether. These amendments were later on extended to the rest of the country in 2005, under the Hindu Succession (Amendment) Act (HSAA).

\section{Empirical Strategy}

Land constitutes one of the most valuable forms of property in rural India (Meinzen-Dick, 2009; Besley and Burgess, 2000); hence, we focus our study in the context of rural India, a setting that allows us to assess whether having greater land rights empower women and how it renders on to the next generation. Below, we first explore the potential mechanisms through which an increase in women's access to property can impact her own economic outcomes.

There are multiple channels through which parents (Generation 0) could have transferred wealth to their daughter (Generation $I$ ) as a result of this amendment. First, through the channel of land inheritance, Generation 0 could give their daughter a share of ancestral property as dictated by the reform. However, post reform, evidence suggests that many

of the Act. The Act also made special provisions for communities that were considered matrilineal. Further, tribal communities in the northeastern states are excluded from the Act since they are ruled by local customs and a few are matrilineal in nature.

$\sqrt[3]{\text { Agarwal }}$ (1994) reports that $65 \%$ of the population in India die without wills, and this percentage is presumed to be higher for rural households.

${ }^{4}$ In India, states have jurisdiction to amend inheritance laws. 
families avoided giving daughters their rightful land inheritance (Agarwal, 1994, Deininger, Goyal and Nagarajan, 2013; Roy, 2015).5 The second channel could be in the form of dowry payments since the reform may have induced parents to compensate their daughters with other forms of wealth transfer rather than part with the family land. Roy (2015) notes that while dowry payments decreased by $28 \%$ for girls below 10 years of age, they increased by $50 \%$ for those closer to marriageable age, i.e., between 11-15 years of age. A third channel may be through increased education investments for girls in order to avoid giving them their rightful inheritance. Deininger, Goyal and Nagarajan (2013) and Roy (2015) find an increase in the number of years of schooling for treated daughters after the implementation of the inheritance rights amendment.

We first answer the question as to whether securing land rights improves women's educational attainment by using a difference-in-differences strategy. There are two sources of variation in a woman's exposure to the property rights reform. Our first source of variation is the timing of a woman's marriage: the policy change is effective for women who were unmarried at the time of the reform in their state. A caveat to using the year of marriage to identify the treated cohort is that parents could delay (those who are gender progressive) or advance (those who do not want to devolve property to their daughters) their daughters' marriage. Hence, we also control for age at marriage to correct for this potential bias. Our second source of variation is the group of four states (HSAA state) that passed the amendment prior to the 2005 national amendment. ${ }^{6}$ While one could argue that women might migrate from a non-HSAA state to an HSAA state after marriage, Roy (2015) notes that this is not of concern since this percentage is close to being negligible (approximately 3\%). Using these two sources of variation, we use a difference-in-differences strategy estimation

\footnotetext{
${ }^{5}$ Sisters voluntarily gave up their claims to ancestral land in favor of their brothers (Saxena, 2013). Apart from cultural norms which discourage women from claiming their rights, the main reason for this is that women want to maintain access to their natal homes in case of "...economic, social, and physical vulnerability in case of marital discord, ill-treatment, marriage break-up or widowhood." (Agarwal, 1994). There is further evidence that instead of giving ancestral property to their daughters, sonless households often adopted sons to give them their property to keep the land under the family name (Agarwal, 1994).

${ }^{6}$ Kerala is excluded from our main estimation since their reform was different than the rest of the country and was long before the rest of the country.
} 
method and estimate the following equation:

$$
e d u c_{i s t}=\alpha+\beta_{1}\left(H S A A_{i s t}\right)+\lambda_{d}+\delta_{t}+X_{i s t} \Pi+\epsilon_{i s t}
$$

where $e d u c_{i s t}$ is the completed years of schooling of a woman $i$ from state $s$ married in year $t$. $H S A A_{\text {ist }}$ is a dummy variable that takes on the value 1 if a woman $i$ belongs to reform state $s$ and was unmarried in the reform year $t$ in her state $s$, and takes on the value 0 if she was not exposed to the reform.

While the IHDS does not provide direct information on a woman's natal family background, the survey records whether a woman married into a household with a similar, better or a worse economic status and whether they are from the same caste. We also control for whether the practice of land dowry is common in their family and if her husband is her blood relative. $]^{7}$ Marrying blood relatives tends to be a common way to ensure that the property does not get devolved to the outside community. Given that the reform may have prompted parents to substitute education for land, controlling for the above two variables is important when assessing the impact on a treated woman's education. Additionally, $X_{i s t}$, is a vector of individual and household characteristics which include caste, woman's age at marriage, number of older women and men in her marital household, below poverty line (BPL) status, and the total land holding. $\lambda_{d}$ are district fixed effects, and $\delta_{t}$ are year of marriage fixed effects. The district fixed effects account for cross-place differences. Since districts are administrative divisions of states, accounting for district fixed effects ensures that we have controlled for unobservable variation at the state level. Finally $\epsilon_{i s t}$ is the error term and all errors are clustered at the district level.

Existing literature has established that a woman's bargaining power in household decisions increases when her education and contribution to household wealth increases and in turn has significant intergenerational benefits (Afridi, Mukhopadhyay and Sahoo, 2016; Bruins, 2017; Duflo, 2003; Murthi, Guio and Drèze, 1995; Lépine and Strobl, 2013; Lundberg,

\footnotetext{
${ }^{7}$ In our dataset, approximately $13.50 \%$ of Hindu rural women are married to their blood relative.
} 
Pollak and Wales, 1997; Qian, 2008). While some studies suggest that mother's contribution to household decision-making is positively associated with resource allocation towards girls (Glick and Sahn, 2000; Rangel, 2006; Reggio, 2011), others find evidence of increased investments towards boys (Haddad and Hoddinott, 1994, Thomas, Contreras and Frankerberg, 2002, Quisumbing and Maluccio, 2003). We extend this literature in the setting of the HSAA; how a mother's exposure to the reform impacts her education and more specifically, her children's educational attainment (Generation II).8 If mothers with higher education place greater value on it, then they could use their bargaining power to increase her children's educational attainment (Afridi, 2010). With respect to the HSAA, in the presence of a son, if mothers impacted by the reform exhibit the same preferences as that of her parents (Generation 0), then she might allocate resources towards increasing her daughters' (Generation II) education, without taking away any resources from the sons. However, we could also find a decrease in children's education in the following scenario. If educated mothers in rural areas deem the opportunity cost of education as high and assess the quality of education as low, they may use their bargaining power to decrease the number of years of children's education. This is especially true in the case for boys since they are favored as rightful inheritors of land assets and hence maybe forced to substitute formal schooling in favor of farming or non-farming related education skills.

We posit that children of mothers who were exposed to the reform are likely to be more educated than women who were not affected by the HSAA. To analyze the intergenerational transfer of education, we estimate the following equation:

$$
y_{i s t}=\alpha+\beta_{2}\left(H S A A_{s t}\right)+\lambda_{d}+\delta_{t}+X_{i s t} \Pi+\epsilon_{i s t}
$$

where $y_{i s t}$ is the measure of age adjusted educational outcome of child $i$ belonging to a mother in state $s$ who was married in the year $t$. Following Quisumbing and Maluccio (2003)

\footnotetext{
${ }^{8}$ It is important to note that since our data is a cross-section between 2004-2005, our results only capture the impact on children in the pre-2005 reform states. Given that the national amendment went into effect only after 2005 , it does not play a role in our estimations.
} 
and Afridi (2010), educational attainment is measured as the deviation of the child's highest grade completed from the average grade attainment for the child's age cohort. This accounts for incomplete years of schooling and provides a consistent measurement of grade attainment relative to her cohort. $H S A A_{s t}, \lambda_{d}$ and $\delta_{t}$ are the same from Equation (1). $X_{i}$ accounts for caste, household size, the age of the child, household income, household occupation, and BPL status. We restrict our sample to children of eligible women aged between 5-14 since Indian children start primary school at age 5 and the legal age to work in the country is 14 years and older. It is possible that an eligible woman has children younger or older than 5-14 years, and hence we include her total number of kids as well. For example, suppose an eligible woman has two children aged 11 and 15 years. Our estimation would only include the 11-year-old child, and hence it is important to control for her total fertility. To account for the age and gender composition of the child's siblings, we include the number of older and younger male and female siblings.

It is important to evaluate the educational attainment of children in the context of their gender and birth-order relative to that of their siblings. While some studies in the developed world find an increase in education for older children (Behrman and Taubman, 1986, Black, Devereux and Salvanes, 2005, Conley and Glauber, 2006), others in the developing world have documented favorable outcomes for the younger siblings (Haan, Plug and Rosero, 2014. Kumar, 2016). In India, son-preference, especially for the oldest sons, can determine the distribution of resources on children in the household. India's patrilineal system fuels this preference for son: while daughters leave their natal home and take with them family assets in the form of dowry, sons traditionally remain in the family home and take on the responsibility of being their parents' support and security during old age. Not surprisingly, sons in rural landowning households are expected to work on family land to contribute to household assets. Son-preference is particularly prevalent in families where the first-born is not a son, affecting the amount of resources received by children (Jayachandran and Pande, 2017). Bhalotra et al. (2016) find that changes to land tenure rights increased son-preference in families whose 
first-born is a girl. A consequence of this pro-male bias is that families tend to be larger and continue to grow until their desired gender mix of children is achieved (Clark, 2000). The presence of a large number of siblings negatively impacts investments in children's health and education (Booth and Kee, 2005). Studies have shown that children, especially daughters in families without an older brother, are breastfeed for a shorter duration (Haan, Plug and Rosero, 2014 Jayachandran and Kuziemko, 2011). Jayachandran and Pande (2017) highlight the child stunting problem in India, and conclude that first-borns in India are taller than their African counterparts, only if they are boys. Additionally, they find similar results that having older sisters is beneficial for younger boys and not for younger girls.

In addition to sibling composition in the households, resource constraints also play an important role in families' allocation decisions amongst children (Haan, Plug and Rosero, 2014; Steelman and Mercy, 1980). If parents' time and finances are divided among a greater number of children, each child receives fewer resources towards their educational development. In Turkey, Dayioğlu, Kirdar and Tansel (2009) find that as the proportion of male siblings in poor families increase, the likelihood of girls being enrolled in schools decrease. However, these effects disappear for wealthy families. Additionally, Parish and Willis (1993) find that in Taiwan, the presence of older sisters in poor families largely benefit the schooling outcomes of younger children, irrespective of their gender. When girls do not have an older brother, a pro-male bias may contribute to sibling rivalry in resources since parents may be saving some funds for when they have sons. Later-born daughters have a higher probability of having an elder brother which could also affect resource allocation towards her if the parents exhibit son-preference (Pande, 2003). In our study, if mothers with greater property rights continue to exhibit son-preference, then in families without an older son, there could be a decrease in her daughters' education. However, in the presence of an older son, younger children (both sons and daughters) might instead, experience an increase in education. Additionally, if these beneficiary mothers are gender neutral, then we might not see any differences in education amongst siblings, irrespective of the sex of the children. Ac- 
counting for birth-order and gender composition of the children in the household, we modify Equation 2 in the following manner:

$y_{i g s t}=\alpha+\beta_{2}\left(H S A A_{s t}\right)+\beta_{3}\left(H S A A_{s t} *\right.$ olderchild $\left._{i g}\right)+\beta_{4}\left(\right.$ olderchild $\left._{i g}\right)+\lambda_{d}+\delta_{t}+X_{i s t} \Pi+\epsilon_{i g s t}$

where olderchild $_{i g}$ is a dummy variable that is equal to 1 if the child $i$ of gender $g$ is the older sibling, and 0 if the child has an older sibling in the 5-14 age category. All other variables are similar to the ones used in Equation 2, $\beta_{2}$ gives the estimate for educational attainment for the younger children, and $\beta_{3}$ reports the difference in education outcomes between the eldest and youngest child in our sample. $\beta_{2}+\beta_{3}$ is the overall effect on the older child.

\section{Data}

We use the 2004-2005 wave of the Indian Human Development Survey (IHDS) to conduct our analysis. IHDS is a nationally representative sample consisting of 41,554 households from 25 states and Union Territories of India and covers 1503 villages and 971 urban neighborhoods. The sample is restricted to landed Hindu households in rural areas, reducing our main sample to 9270 households. The sample evaluating children's education is restricted to individuals between the ages of 5 and 14 .

The IHDS contains information on household characteristics such as religion, caste, size of land holding, main household occupation, household income, and detailed demographic characteristics including years of schooling. A section of the survey is devoted to eligible women, those who are currently married and are between 15-49 years of age. Specifically, the survey records a woman's year of marriage, allowing us to identify women who were exposed to the reform versus those who were not. We are, therefore, able to create the treatment and control group in the following manner. An unmarried women in Andhra Pradesh, for example, at the time of the reform (which passed it in 1986) is in our treatment 
group. Women already married by 1986 were excluded from the benefits of the property rights reform and thus are in our control group. We use this method for all 16 states to form our treatment and control groups. The reform states are Andhra Pradesh (1986), Karnataka (1994), Kerala (1976), Maharashtra (1994) and Tamil Nadu (1989).The non-HSAA states are Bihar, Chhattisgarh, Gujarat, Haryana, Himachal Pradesh, Jharkhand, Madhya Pradesh, Orissa, Punjab, Rajasthan, Uttaranchal, and Uttar Pradesh.9

Descriptive statistics are presented in Table 1. Reform states have a higher percentage of Hindus than non-reform states. Among Hindus in rural households, the percentage of higher caste and lower caste (Scheduled Tribes / Scheduled Castes / Other Backward Castes) individuals are similar in the reform and non-reform states. Approximately $53 \%$ of households in the reform states and $67 \%$ in non-reform states have some form of land holding. However, the size of land holding is smaller in the non-reform states, with an average size of 0.69 hectares compared to 0.72 hectares in the reform states. Although the average household income is similar for these two groups, non-reform states have a higher percentage of the population (32\%) living below the poverty line than the reform states (13\%). We see this repeated within reform states, where the percentage of BPL households is greater in the control group than the treatment group. It is also important to note that the average land holding in a treated woman's household is 0.68 hectares, which is lower than the average land holding (0.75 hectares) in a control woman's household.

While women's age at marriage in both groups is around 16 years, those in reform states have fewer children compared to those in non-reform states. Both reform and non-reform states have more boys than girls in their households. Within reform states, women affected

\footnotetext{
${ }^{9}$ In addition to Kerala not being included in our sample, we also drop West Bengal, Jammu \& Kashmir $(\mathrm{J} \& \mathrm{~K})$ and the Northeastern states. In the late 1970s, West Bengal passed a successful and highly ambitious redistributive land reform measure, which most likely affected the amount of land women inherited in the 1970s and 1980s. Since land redistributive measure in West Bengal was during the property rights amendment in the 5 treatment states, we exclude West Bengal from the control group. Additionally, West Bengal and Assam followed the Dayabhaga system of property rights, which allowed daughters to inherit all types of property, making them unsuitable as valid control groups. $J \& K$ is not in the sample since it was never part of the 1956 HSA. Union Territories are also not considered in our sample since they differ both politically and administratively from the rest of the states in India. We also exclude Delhi since we focus only on the rural areas.
} 
by the reform married later and had more children than those not affected by the reform. The pattern of more boys than girls is continues to hold in the reform states for both treated and control groups of women. We also see an education gap between eligible women and their husbands in both reform states and non-reform states. However, both men and women in the reform states had, on average, more years of education than their counterparts in nonreform states. Women in reform states have a higher educational attainment than women in non-reform states; the gap is approximately 1 year.

\section{$5 \quad$ Falsification Test}

The identifying assumption in a difference-in-differences analysis is that the parallel trend assumption holds true; that the educational outcomes of the treatment and control group of women would have been the same in the absence of the reform. The estimated coefficients capture the true causal effect of the reform only if the variation in the reform's timing is not related to unobserved shocks and trends that differentially affected women who were unmarried at the time the reform was introduced in her state. In our study, one challenge to our difference-in-differences analysis is that there are substantial between the reform and non-reform states (Table 1). For instance, women in the reform states tend to be married at a later age compared to those in the non-reform states, potentially influencing their time in school. Due to these baseline differences between the treated and control group, we use district fixed effects and time fixed effects that account for cross-place and cross-time differences. Nevertheless, it is important for us to test the validity of the difference-indifferences strategy.

We conduct a falsification test by examining the pre-reform education patterns of Generation I women that should not have been affected by the changes to property rights. In

Table 2, Column 1, we estimate Equation 1 for only the Muslim population. Since the Hindu Succession Act does not affect Muslims, we should not expect women in Muslim households 
to be impacted by the reform. In our data, we have $11 \%$ rural Muslim households in the non-reform states and approximately $4 \%$ rural Muslim households in the reform states. We find that the coefficient for the treatment variable HSA reform is not statistically significant. These findings lend confidence to the validity of the difference-in-differences strategy detailed in the previous section.

In Column 2, we include all four reform states in our treatment group but give them a false reform start date of 1981 and we restrict their data until the start of the reform in the respective states. Using an equation analogous to Equation 1, we find that the coefficient is small and positive but not statistically significant for treated women in rural households and this continues to hold for treated women in landed rural households. This indicates a common pre-trend and provides support for the identification strategy.

\section{Results}

In Table 3, we assess if the reform lead Generation 0 to compensate their daughters with human capital via more education. Tables 4 , 5 and 6 focus on the intergenerational effect of the reform.

\subsection{Impact of Inheritance Laws on Women's Education (Generation I)}

Table 3 presents results from estimating changes to women's property rights on their educational attainment. Column 1 presents results with basic controls including age at marriage, if the household is below poverty line (BPL), caste, number of older men and women in the household, year of marriage fixed effects, and district fixed effects. Column 2 adds controls that help us explain the socio-economic background of a woman's natal household. The vari-

ables account for differences between the spouses' economic status at the time of marriage, whether the couple is of the same caste, whether the practice of land dowry is common in 
their family and if her husband is her blood relative. In Column 3, we include the total land holding of the woman's marital family to account for the asset holding of her marital household.

The results are first presented for the full sample (both landed and non-landed) of households in Panel A. For all our aforementioned specifications, the results are positive and significant. Women impacted by the HSA reforms completed an average of 0.40 years of schooling more than women who were not. Since land is an important asset in rural areas, the inheritance reform is likely to play a role in securing land. In Panel B of Table 3, the results presented are restricted to the sample of landed households. We proxy a woman's natal land ownership with information from her marital household. In Column 1, we find a 0.52 increase in completed years of education, significant at the $10 \%$ level. Using proxies for the women's natal households, we continue to find a significant increase of 0.54 years of education for those who were impacted by the reform. While the results in columns 3 are not significant at the conventional levels (the p-value is 0.105 ) the magnitude of the coefficients is positive and similar to the previous specifications. On average, women impacted by the reform in landed households earned an additional 0.50 years of education.

Overall, we find that the amendments to the Hindu Succession Amendment Act significantly increased women's educational attainment. Our results are in line with Deininger, Goyal and Nagarajan (2013) and Roy (2015) who also find evidence of an increase in women's education due to the HSAA. While we are unable to determine if women were compensated with more human capital in lieu of physical capital, our results provide some suggestive evidence towards this channel of wealth transfer.

\subsection{Intergenerational Impact of Property Rights Reform}

\subsubsection{Impact on Children's Education (Generation $I I$ )}

Does the positive impact of the HSA reform on women translate to her children? Empirical analysis of the relationship between mothers' increase in education (due to better property 
rights) and her children's educational attainment is presented in Table 4. All the results focus on landed rural households where children are between ages 5 - 14. We concentrate on households with one to four children since this is typical of a family in rural India. Results presented in Column 1 show no significant differences in the educational attainment between children belonging to mothers impacted by the reform compared to those not. We also assess the intergenerational impact by gender of the child. The coefficients suggest a decrease in education for both girls and boys, however the results are not significant.

At first glance, the results indicate no evidence of intergenerational transmission of property rights reform. To properly evaluate a woman's bargaining power in the household, it is important to consider her position in the household relative to her husband's. For example, if husbands are less educated than their wives (or earn less than their wives), then in the context of decision-making, a woman's increase in education might not have a significant impact in her household due to existing social customs and norms. On the other hand, if husbands are more educated than their wives, then in the absence of status conflict, a woman's increase in education maybe permitted to have a positive impact on her household well-being.

In this context, we re-estimate Equation (2) between two groups of households: one where the father's education is less than that of the child's mother (Column 2) and the other where the father is equally or more educated than the mother (Column 3). The relative educational difference between parents present an interesting set of results. In the full sample, where mothers are more educated than fathers, there is almost a 0.19 standard deviation significant decrease in children's educational attainment. Dividing the sample by the gender of the child presents a few surprising results. While we do not see any impact of father's relative education for the sample of daughters, we see the negative result mimicked for sons. Amongst households where mothers are more educated than fathers, boys see a significant decrease of 0.27 standard deviations in their education. For households where fathers' education level is greater than or equal to that of the mothers, we see no significant 
results for both girls and boys.

The above results suggest that in evaluating the effects of women's empowerment, it is important to conduct the study accounting for a woman's relative standing in her family. As seen in our analyses, mothers who were of higher status in terms of education than their husbands, are not translating their higher decision-making power to increase sons' education. We argue that in such households the sons' education follows the fathers' education. Since these results are restricted to landed households, sons' might be taken out of schools to teach more farming skills so that they are well-equipped to maintain their family's land. Furthermore, recent reports from the Census of India indicate a rapid decline in education statistics.10 10 Based on the nationally representative data, National Sample Survey, approximately 39\% of rural students in 2011-12 were no longer enrolled in school. The survey highlights that one of the primary reasons for children between 5-14 dropping out of school was that education was deemed unnecessary. 11 This is in part due to the rising wages in India, making the opportunity cost of education higher, especially for boys in rural households. While we find no statistically significant results for girls, we do find an increase in their educational attainment. Anecdotal evidence suggests that, in spite of households being wary of school quality, they consider sending their daughters to schools to keep their daughters safe. Thus, although the results are not statistically significant, they hold some economic significance.

\subsubsection{Role of Birth-Order and Gender Composition of Children}

In Tables 5 and 6, we explore the role of gender and birth-order in assessing the intergenerational impact of the property rights reform. There is overwhelming evidence of son preference in Hindu households exhibited by a skewed sex-ratio, high girl child mortality, and low parental investment in daughter's education. In a patriarchal society, families may invest

\footnotetext{
${ }_{10}^{10}$ http://www .livemint.com/Opinion/h9bmbiINg0iHOBcrbZ7ggO/Why-students-in-India-drop-out. html

${ }^{11}$ Children between ages 5-9 in 2004-05 are aged 11-15 in 2011-12
} 
in sons more than daughters since the former carry on the family name, provide a safety net for parents in their old age, and in rural landed households work on the land to contribute to family wealth (Pande and Astone, 2007). As discussed in the empirical section, households may make investment decisions based on the gender composition of their children. These findings make it imperative to analyze whether the negative intergenerational impact of the reform, especially for boys, is being driven by the gender and birth-order of the children.

Our preliminary focus is on households where the children of eligible women are gender homogeneous (Table 5). In Columns 1 and 2, we focus on children from "All Boy" (BB) household; these children are between 5 and 14 years and belong to households where the eligible woman has either two or three children between this age range. ${ }^{12}$ In similar manner, Columns 3 and 4 looks at "All Girl" (GG) households. If households were gender neutral, then for GG households, one would not see a difference between the older and younger daughters. However, if son preference exists, and empowered women use their bargaining power to exert this preference, one could see a difference in age-adjusted educational attainment between the older and younger daughters. If BB households had son preference or exhibited gender neutrality, then one would see no difference between the younger and older child. However, in the event that families are resource constrained, they may choose to invest in the older sons. Thus, focusing on gender homogeneous households allows us to assess if reform mothers exhibit son preference through the channel of education. The modal number of children is between 2 to 3 and so we restrict the sample to reflect that family size. 13

In BB households, on average, we find a 0.29 standard deviation significant decrease in years of completed schooling for sons of empowered mothers relative to control mothers (Column 1). Accounting for birth-order, we find that the education level of the younger child is 0.34 standard deviations lower when compared to control households (Column 2, Row 1). The difference between the younger and the older son (Column 2, Row 2) is not significant,

\footnotetext{
${ }^{12}$ One caveat to note is that there maybe other children in the household who are not the eligible woman's children and we do not pick them up in our estimation.

${ }^{13}$ This is similar to Jayachandran and Pande (2017) who also find that the modal preference in India is two children.
} 
implying that there is no significant gap in educational attainment between these children. In GG households, we see an overall decrease of approximately 0.27 standard deviation in years of completed schooling for the girl child in a treated household (Column 3). In this situation as well, the gap in education between the siblings is not statistically significant. A similar pattern emerges for the younger girl child, there is a 0.37 standard deviation decrease in educational attainment (significant at the $5 \%$ level). Overall, in gender homogeneous households, the children of treated mothers continue to perform worse, the negative effect is persistent for boys even when birth-oder is accounted for. If treated mothers viewed education as an asset, then under the assumption of son preference, our results would have pointed towards the older boy child receiving significantly more education than the control households and that there is either no effect or a negative on the older girl child's educational attainment. Since we find no such evidence, parents have most likely assessed the opportunity cost of education to be high and may have invested in their sons through another channel. Our results are in line with the literature that find a decrease in investments for younger children.

In Table 6, we shift towards gender heterogeneous households where families have two children within the 5 to 14 age group. Columns 1 and 2 look at households where the older child is a boy, "Boy-Girl" (BG), and Columns 3 and 4 look at households where the older child is a girl, "Girl-Boy" (GB). In these cases, if families exhibit son preference, then in GB households, one could see the younger child receiving more investments in education than the older child and in BG households, the reverse would hold true. While the average impact on children in both sets of households is negative, in GB households the older girl child has 0.37 standard deviation more education than her younger brother, although the overall impact on her is negative relative to the control group. This provides some strength to the rationale that mothers impacted by the reform may be doing one of two things: they are either asserting their preferences in the household to improve their daughters' education or they are exhibiting the same preferences as her parents did: compensating daughters 
with education instead of giving their rightful inheritance. For BG households, there is no significant difference between the older and younger siblings. All these results point to the fact that in the presence of son-preference among treated mothers, their increased education is not translating to their sons' educational outcome and that they are not using their power to increase their son's years of schooling.

\section{Robustness Checks: Year of Birth and NSSO Data}

Our analysis, thus far, has shown a significant increase in women's education due to the HSAA. A potential endogeneity issue with using the year of marriage to identify our treated group is that the year of marriage could be impacted by the year of reform. On the one hand, parents could intentionally get their daughters married early (if they had anticipated a change to the succession law). On the other hand, they could have delayed their daughters' marriage and increased their education levels to avoid giving them property. Thus, although the policy was for women who were unmarried at the time of the reform, we identify the treatment group using another source of variation that is independent of the year in which the reform was passed. Also, since the national amendment to the HSA went into effect in 2005, and that coincides with the 2004-05 round of IHDS used in our study, we use a different data set to conduct this robustness check.

For our analysis we use the Consumption Expenditure Survey conducted by the National Sample Survey Organization (NSSO) for 2001- 02, 2003, and 2004-05. The NSSO surveys are nationally representative household surveys and they cover nearly all the districts in India. The NSSO data set does not have the years of education; it only reports the level of education completed by each member of the household. Thus, we translate education level to the number of years of schooling completed by each individual in the household. We use the maximum number of years one spends in school at a particular education level without failing at any stage of the process. For example, the education level corresponding to high school, therefore, translates to 16 years in school. 
The primary equation we estimate is the similar to our main estimation:

$$
y_{i c s}=\alpha_{1}+\beta_{1}\left(H S A A_{i c s}\right)+\lambda_{s}+\delta_{c}+\gamma_{s} *\left(\text { cohort }_{c}\right)+X_{i c s} \Pi+\epsilon_{i c s}
$$

where $y_{i c s}$ is the education of the mother $i$ who belongs to cohort $c$ in state $s . H S A A_{i c s}$ is the treatment variable that takes on the value 1 for treated cohorts $c$ in the reform state s. The treated cohorts are the following: 0-5 (primary school), 6-10 (middle school), 11-15 (high school) and 16-18 (grades 11-12). The omitted group is the cohort above 18 at the time of the reform. $\lambda_{s}$ controls for state trends, $\delta_{c}$ are cohort fixed effects. To account for any differential effects of the policy, we include the term $\gamma_{s} *\left(\right.$ cohort $\left._{c}\right)$ to control for state specific cohort trends. Finally, $\epsilon_{i c s}$ is the error term. To control for serial correlation and heteroskedasticity, the standard errors are clustered at the district level. The coefficient of interest is $\beta_{1}$ which gives the differential impact of education for each of the cohorts compared to women above 18 years of age at the time of the reform.

The results of this estimation are presented in Table 7. Column 1 shows the impact on women aged 18 or less at the time of reform the compared to those aged 18 or more, controlling for state and cohort fixed effects. We find that the HSAA has a significant impact on education. The average increase in the years of education for all women exposed to the reform was 0.72 years. In Column 2, we focus on mothers who had been exposed to treatment by cohort (younger cohort were below 10 years during the time of reform and older cohort were above 10 years but below 18 at the time of reform), we find that only that there is a positive and significant effect only for the younger cohort. The number of years of education increases by 0.83 years for the younger cohort. We find similar results in Column 3, which further breaks down the treatment variable into different cohorts as specified in the empirical section. We find that the younger cohorts experience significant changes in educational achievement due to the HSAA, where as the older cohorts do not experience any boost in terms of education as a result of the reform. In fact, for Cohort 3 ((11-15) the effect is negative, although not significant. 
Quite often, by age 16, most women in rural India are married, in spite of the legal marriage age for women being 18. ${ }^{14}$ The results presented for the oldest cohort likely stem from the fact that girls in that age group may have already been married and therefore not in school at the time of reform. For those girls who were in school, they were also likely to get married before the age of 18. Although this cohort is technically in the treated group, the practice of marrying daughters by the age of 18 allows us to use this last cohort to conduct a falsification test to ascertain if the impact of HSAA is restricted only to the unmarried girl at the time of reform or whether there are spillover effects in the control group. As we see in the table, the oldest cohort indeed does not benefit from the reform in terms of educational attainment. This gives confidence in our results.

\section{Conclusion}

In this study, we examine the impact of improving women's access to property motivated by the amendments to the Hindu Succession Act. The changes allowed unmarried women to be equal shareholders as their brothers, specifically with respect to ancestral property and agricultural property. Given widespread and persistent gender discrimination in tenure rights, this amendment was a significant move towards gender equality. By the early 1990s, five states in India had passed these reforms, and we use this natural experiment to evaluate its impact on women's education. We further look at the intergenerational outcomes of the reform by examining the education outcomes of the children of women affected by the reform.

Using the 2004-05 round of the Indian Human Development Survey (IHDS), we employ a difference-in-differences strategy where the treated group of individuals are women who were unmarried at the time of the reform and belonged to the five reform states. We find that years of schooling are significantly higher for women directly impacted by the reform (Generation I). While we find no impact on the education of daughters of women exposed to

\footnotetext{
${ }^{14}$ The 2013 UNICEF Statistics and Monitoring Section, Division of Policy and Strategy reported that India is the top country with child brides. The official number is 10063 (in thousands) woman aged 20-24 at the time of the survey who were married before 15 .
} 
the reform, our results indicate that educational attainment for boys decreases significantly in households with the treated mother. This impact is more prevalent in households where the father is less educated than the mother. For families where husbands are either equally or more educated than their wives, the sons are not negatively affected. We explore the role of birth order and the gender composition of children to assess if empowered mothers use their bargaining power to exhibit preference for an eldest male child through the education channel, and find no evidence to support this assumption.

Although our results are from a reduced-form estimation, it does provide some suggestive evidence towards the argument that families find the opportunity cost of school to be high in an environment of rising wages, especially for boys. Additionally, there is a need to investigate the factors behind the decrease in boys' education. One way to correct for this could be to make the opportunity cost of dropping out of school more expensive, by incentivizing their demand for education and increasing awareness among parents about the returns to formal education in conjunction with farming and non-traditional education. 


\section{References}

Afridi, Farzana. 2010. "Women's empowerment and the goal of parity between the sexes in schooling in India." Population Studies, 64(2): 131-145. PMID: 20467964.

Afridi, Farzana, Abhiroop Mukhopadhyay, and Soham Sahoo. 2016. "Female labor force participation and child education in India: evidence from the National Rural Employment Guarantee Scheme." IZA Journal of Labor 65 Development, 5(1): 7.

Agarwal, Bina. 1994. A Field of One's Own: Gender and Land Rights in South Asia. Cambridge South Asian studies, Cambridge University Press.

Allendorf, Keera. 2007. "Do Women's Land Rights Promote Empowerment and Child Health in Nepal?" World Development, 35(11): 1975 - 1988.

Anderson, Siwan, and Garance Genicot. 2015. "Suicide and property rights in India." Journal of Development Economics, 114: 64-78.

Behrman, Jere R., and Paul Taubman. 1986. "Birth Order, Schooling, and Earnings." Journal of Labor Economics, 4(3): S121-S145.

Besley, Timothy, and Robin Burgess. 2000. "Land Reform, Poverty Reduction, and Growth: Evidence from India." The Quarterly Journal of Economics, 115(2): 389-430.

Bhalotra, Sonia, Abhishek Chakravarty, Dilip Mookherjee, and Francisco J. Pino. 2016. "Property Rights and Gender Bias: Evidence from Land Reform in West Bengal." University of Chile, Department of Economics, Working Paper, wp422.

Black, Sandra E., Paul J. Devereux, and Kjell G. Salvanes. 2005. "The More the Merrier? The Effect of Family Size and Birth Order on Children's Education." The Quarterly Journal of Economics, 120(2): 669-700.

Booth, Alison L., and Hiau Joo Kee. 2005. "Birth Order Matters: The Effect of Family Size and Birth Order on Educational Attainment." Institute for the Study of Labor, IZA Discussion Paper No. 1713.

Bruins, Marianne. 2017. "Women's Economic Opportunities and the Intra-household Production of Child Human Capital." Labour Economics, 44: 122 - 132.

Clark, Shelley. 2000. "Son preference and sex composition of children: Evidence from india." Demography, 37(1): 95-108. 
Conley, Dalton, and Rebecca Glauber. 2006. "Parental Educational Investment and Children's Academic Risk: Estimates of the Impact of Sibship Size and Birth Order from Exogenous Variation in Fertility." Journal of Human Resources, 41(4): 722-737.

Currie, Janet, and Enrico Moretti. 2003. "Mother's Education and the Intergenerational Transmission of Human Capital: Evidence from College Openings*." The Quarterly Journal of Economics, 118(4): 1495-1532.

Dayioğlu, Meltem, Murat G. Kirdar, and Aysit Tansel. 2009. "Impact of Sibship Size, Birth Order and Sex Composition on School Enrolment in Urban Turkey*." Oxford Bulletin of Economics and Statistics, 71(3): 399-426.

Deere, Carmen Diana, and Cheryl R. Doss. 2006. "The Gender Asset Gap: What Do We Know and Why Does It Matter?" Feminist Economics, 12(1-2): 1-50.

Deininger, Klaus, Aparajita Goyal, and Hari Nagarajan. 2013. "Women's inheritance rights and intergenerational transmission of resources in India." Journal of Human Resources, 48(1): 114-141.

Duflo, Esther. 2003. "Grandmothers and Granddaughters: Old-Age Pensions and Intrahousehold Allocation in South Africa." The World Bank Economic Review, 17(1): 1-25.

Duflo, Esther. 2012. "Women Empowerment and Economic Development." Journal of Economic Literature, 50(4): 1051-1079.

Glick, Peter, and David E. Sahn. 2000. "Schooling of girls and boys in a West African country: the effects of parental education, income, and household structure." Economics of Education Review, 19(1): 63 - 87.

Haan, Monique De, Erik Plug, and José Rosero. 2014. "Birth Order and Human Capital Development: Evidence from Ecuador." Journal of Human Resources, 49(2): 359392.

Haddad, Lawrence, and John Hoddinott. 1994. "Women's income and boy-girl anthropometric status in the Côte d'Ivoire." World Development, 22(4): 543 - 553.

Handa, Sudhanshu. 1996. "Maternal Education and Child Attainment in Jamaica: Testing the Bargaining Power Hypothesis?" Oxford Bulletin of Economics and Statistics, 58(1): 119-137.

Harari, Mariaflavia. 2016. "Women's Inheritance Rights and Bargaining Power: Evidence from Kenya." Working Paper. 
Heath, Rachel, and Xu Tan. 2016. "Intrahousehold bargaining, female autonomy, and labor supply: Theory and evidence from India." Working Paper.

Jayachandran, Seema, and Ilyana Kuziemko. 2011. "Why do mothers breastfeed girls less than boys: Evidence and Implications for child health in India." The Quarterly Journal of Economics, 126(3): 1485-1538.

Jayachandran, Seema, and Rohini Pande. 2017. "Why Are Indian Children So Short? The Role of Birth Order and Son Preference." American Economic Review, 107(9): 26002629 .

Kumar, Santosh. 2016. "The effect of birth order on schooling in India." Applied Economics Letters, 23(18): 1325-1328.

Lépine, Aurélia, and Eric Strobl. 2013. "The Effect of Women'ǍŹs Bargaining Power on Child Nutrition in Rural Senegal." World Development, 45: 17 - 30.

Lundberg, Shelly J., Robert A. Pollak, and Terence J. Wales. 1997. "Do Husbands and Wives Pool Their Resources? Evidence from the United Kingdom Child Benefit." The Journal of Human Resources, 32(3): 463-480.

Meinzen-Dick, Ruth. 2009. "Property Rights for Poverty Reduction?" UN Economic \& Social Affairs DESA Working Paper, No. 91.

Mishra, Khushbu, and Abdoul G. Sam. 2016. "Does Women's Land Ownership Promote Their Empowerment? Empirical Evidence from Nepal." World Development, 78: 360 - 371.

Murthi, Mamta, Anne-Catherine Guio, and Jean Drèze. 1995. "Mortality, Fertility, and Gender Bias in India: A District-Level Analysis." Population and Development Review, 21(4): 745-782.

Oreopoulos, Philip, Marianne E. Page, and Ann Huff Stevens. 2006. "The Intergenerational Effects of Compulsory Schooling." Journal of Labor Economics, 24(4): 729 760.

Pande, Rohini P. 2003. "Selective gender differences in childhood nutrition and immunization in rural India: The role of siblings." Demography, 40(3): 395-418.

Pande, Rohini P., and Nan Marie Astone. 2007. "Explaining son preference in rural India: the independent role of structural versus individual factors." Population Research and Policy Review, 26(1): 1-29. 
Parish, William L., and Robert J. Willis. 1993. "Daughters, Education, and Family Budgets Taiwan Experiences." The Journal of Human Resources, 28(4): 863-898.

Peterman, Amber. 2011. "Women's Property Rights and Gendered Policies: Implications for Women's Long-term Welfare in Rural Tanzania." The Journal of Development Studies, 47(1): 1-30. PMID: 21280416.

Qian, Nancy. 2008. "Missing Women and the Price of Tea in China: The Effect of SexSpecific Earnings on Sex Imbalance." The Quarterly Journal of Economics, 123(3): 12511285.

Quisumbing, Agnes R., and John A. Maluccio. 2003. "Resources at Marriage and Intrahousehold Allocation: Evidence from Bangladesh, Ethiopia, Indonesia, and South Africa*." Oxford Bulletin of Economics and Statistics, 65(3): 283-327.

Rangel, Marcos A. 2006. "Alimony Rights and Intrahousehold Allocation of Resources: Evidence from Brazil." The Economic Journal, 116(513): 627-658.

Reggio, Iliana. 2011. "The influence of the mother's power on her child's labor in Mexico." Journal of Development Economics, 96(1): 95 - 105.

Rosenblum, Daniel. 2015. "Unintended Consequences of Women's Inheritance Rights on Female Mortality in India." Economic Development and Cultural Change, 63(2): 223-248.

Roy, Sanchari. 2015. "Empowering women? Inheritance rights, female education and dowry payments in India." Journal of Development Economics, 114: 233 - 251.

Saxena, Naresh C. 2013. "Land, Livestock and Rights of Women in Rural India." In Women, Land and Power in Asia., ed. Govind Kelkar and Maithreyi Krishnaraj, Chapter 11. New Delhi:Routledge.

Sircar, Ashok K., and Sohini Pal. 2014. "What is Preventing Women from Inheriting Land? A Study of the Implementation of the Hindu Succession (Amendment) Act 2005 in Three States in India." Landesa, India, Paper prepared for presentation at the "2014 World Bank Conference On Land and Poverty?, The World Bank-Washington DC, March 24-27, 2014,.

Steelman, Lala Carr, and James A. Mercy. 1980. "Unconfounding the Confluence Model: A Test of Sibship Size and Birth-Order Effects on Intelligence." American Sociological Review, 45(4): 571-582. 
Thomas, Duncan, Dante Contreras, and Elizabeth Frankerberg. 2002. "Distribution of power within the household and child health." University Library of Munich, Germany MPRA Paper 80075.

Wang, Shing-Yi. 2014. "Property rights and intra-household bargaining." Journal of Development Economics, 107: 192 - 201.

Wiig, Henrik. 2013. "Joint Titling in Rural Peru: Impact on Women's Participation in Household Decision-Making." World Development, 52(Supplement C): $104-119$. 


\section{Table 1}

\section{Descriptive Statistics}

\begin{tabular}{|c|c|c|c|c|c|}
\hline & \multirow{3}{*}{$\begin{array}{c}\text { Full Sample } \\
\\
\text { (1) }\end{array}$} & \multirow{3}{*}{$\begin{array}{c}\text { Non-Reform States } \\
\\
(2)\end{array}$} & \multicolumn{3}{|c|}{ Reform States } \\
\hline & & & All & Treated & Control \\
\hline & & & $(3)$ & $(4)$ & $(5)$ \\
\hline Eligible Woman's Years of Education & $\begin{array}{c}2.80 \\
(3.82)\end{array}$ & $\begin{array}{l}2.37 \\
(3.63)\end{array}$ & $\begin{array}{c}3.35 \\
(3.98)\end{array}$ & $\begin{array}{c}4.44 \\
(4.35)\end{array}$ & $\begin{array}{c}2.47 \\
(3.41)\end{array}$ \\
\hline Eligible Woman's Age & $\begin{array}{l}32.51 \\
(8.03)\end{array}$ & $\begin{array}{l}32.40 \\
(8.07)\end{array}$ & $\begin{array}{l}32.65 \\
(7.98)\end{array}$ & $\begin{array}{l}25.91 \\
(4.74)\end{array}$ & $\begin{array}{l}38.04 \\
(5.60)\end{array}$ \\
\hline Age at marriage & $\begin{array}{l}16.45 \\
(3.03)\end{array}$ & $\begin{array}{l}16.24 \\
(3.08)\end{array}$ & $\begin{array}{l}16.72 \\
(2.94)\end{array}$ & $\begin{array}{l}17.45 \\
(2.89)\end{array}$ & $\begin{array}{l}16.14 \\
(2.83)\end{array}$ \\
\hline Household Size & $\begin{array}{c}5.70 \\
(2.28)\end{array}$ & $\begin{array}{c}6.21 \\
(2.44)\end{array}$ & $\begin{array}{c}5.04 \\
(1.88)\end{array}$ & $\begin{array}{l}5.05 \\
(1.91)\end{array}$ & $\begin{array}{c}5.03 \\
(1.85)\end{array}$ \\
\hline Number of Children & $\begin{array}{c}2.02 \\
(1.54)\end{array}$ & $\begin{array}{c}2.39 \\
(1.62)\end{array}$ & $\begin{array}{c}1.55 \\
(1.28)\end{array}$ & $\begin{array}{l}1.79 \\
(1.14)\end{array}$ & $\begin{array}{c}1.35 \\
(1.34)\end{array}$ \\
\hline Number of boys & $\begin{array}{c}1.23 \\
(1.06)\end{array}$ & $\begin{array}{c}1.44 \\
(1.13)\end{array}$ & $\begin{array}{c}0.97 \\
(0.89)\end{array}$ & $\begin{array}{c}0.98 \\
(0.86)\end{array}$ & $\begin{array}{l}0.96 \\
0.93\end{array}$ \\
\hline Number of girls & $\begin{array}{c}1.14 \\
(1.06)\end{array}$ & $\begin{array}{c}1.34 \\
(1.21)\end{array}$ & $\begin{array}{c}0.89 \\
(0.96)\end{array}$ & $\begin{array}{c}0.92 \\
(0.92)\end{array}$ & $\begin{array}{c}0.88 \\
(0.99)\end{array}$ \\
\hline Household Income & $\begin{array}{c}32151.41 \\
(27020.37)\end{array}$ & $\begin{array}{c}31896.50 \\
(27553.97)\end{array}$ & $\begin{array}{c}32478.31 \\
(26319.60)\end{array}$ & $\begin{array}{c}32378.45 \\
(25437.04)\end{array}$ & $\begin{array}{c}32558.23 \\
(27009.99)\end{array}$ \\
\hline Land Owner & $\begin{array}{c}0.60 \\
(0.48)\end{array}$ & $\begin{array}{c}0.67 \\
(0.47)\end{array}$ & $\begin{array}{c}0.53 \\
(0.49)\end{array}$ & $\begin{array}{c}0.47 \\
(0.49)\end{array}$ & $\begin{array}{c}0.57 \\
(0.49)\end{array}$ \\
\hline Total Land (in hectares) & $\begin{array}{c}0.70 \\
(1.49)\end{array}$ & $\begin{array}{c}0.69 \\
(1.39)\end{array}$ & $\begin{array}{c}0.72 \\
(1.61)\end{array}$ & $\begin{array}{c}0.68 \\
(1.77)\end{array}$ & $\begin{array}{c}0.75 \\
(1.45)\end{array}$ \\
\hline Below Poverty Line & $\begin{array}{c}0.24 \\
(0.43)\end{array}$ & $\begin{array}{c}0.32 \\
(0.46)\end{array}$ & $\begin{array}{c}0.13 \\
(0.33)\end{array}$ & $\begin{array}{c}0.11 \\
(0.32)\end{array}$ & $\begin{array}{c}0.14 \\
(0.35)\end{array}$ \\
\hline Hindus & $\begin{array}{c}0.91 \\
(0.29)\end{array}$ & $\begin{array}{c}0.88 \\
(0.33)\end{array}$ & $\begin{array}{c}0.94 \\
(0.23)\end{array}$ & $\begin{array}{c}0.94 \\
(0.24)\end{array}$ & $\begin{array}{c}0.95 \\
(0.22)\end{array}$ \\
\hline High Caste & $\begin{array}{c}0.17 \\
(0.38)\end{array}$ & $\begin{array}{c}0.16 \\
(0.37)\end{array}$ & $\begin{array}{c}0.18 \\
(0.38)\end{array}$ & $\begin{array}{c}0.18 \\
(0.38)\end{array}$ & $\begin{array}{c}0.18 \\
(0.39)\end{array}$ \\
\hline $\mathrm{SC} / \mathrm{ST}$ & $\begin{array}{c}0.82 \\
(0.38)\end{array}$ & $\begin{array}{c}0.83 \\
(0.37)\end{array}$ & $\begin{array}{c}0.82 \\
(0.39)\end{array}$ & $\begin{array}{c}0.82 \\
(0.38)\end{array}$ & $\begin{array}{c}0.82 \\
(0.38)\end{array}$ \\
\hline No. of Observations & 10582 & 6614 & 4468 & 1799 & 2669 \\
\hline
\end{tabular}

Notes: The data set is from the 2004-05 round of IHDS. Standard errors are in parentheses. Column 1 presents summary statistics for the full sample, Column 2 for the non-reform states. We then report the descriptive statistics for reform states, divided between the full sample (Column 3), for treated group of women (Column 4), and for control group of women (Column 5). 
Table 2

Falsification Test

\begin{tabular}{|c|c|c|c|c|}
\hline & \multicolumn{2}{|c|}{$\underline{\text { Muslims }}$} & \multicolumn{2}{|c|}{ Pre-Trends/Hindus } \\
\hline & All & Landed & All & Landed \\
\hline & (1) & $(2)$ & $(3)$ & $(4)$ \\
\hline Unmarried at the time of Reform & $\begin{array}{c}0.089 \\
(0.647)\end{array}$ & $\begin{array}{c}-0.960 \\
(0.872)\end{array}$ & $\begin{array}{c}0.134 \\
(0.265)\end{array}$ & $\begin{array}{c}0.084 \\
(0.287)\end{array}$ \\
\hline No. of Observations & 933 & 457 & 8652 & 5468 \\
\hline$R^{2}$ & 0.49 & 0.56 & 0.30 & 0.36 \\
\hline
\end{tabular}

Notes: $* * *, * *, *$ denote significance at $1 \%, 5 \%$ and $10 \%$ respectively. The dependent variable is the level of education (measured in number of years) completed by the mother. The sample is restricted to households in rural areas. Sample of states does not include Jammu \& Kashmir and the North Eastern states. All regressions include district fixed effects, year of marriage fixed effects and all other control variables described in our empirical specification. Regressions include sample weights as well. The odd columns present results for all households, whereas the even columns are restricted to only the landed households. Columns 1 and 2 report results for the Muslim population and Columns 3 and 4 report results for a "false" reform date of 1981. 
Table 3

Difference-in-Differences Estimates of Hindu Succession Amendment Act on Mothers' Education

\begin{tabular}{|c|c|c|c|}
\hline & (1) & $(2)$ & $(3)$ \\
\hline & \multicolumn{3}{|c|}{ Panel A: Full Sample } \\
\hline Unmarried at the time of Reform & $\begin{array}{l}0.404^{*} \\
(0.220)\end{array}$ & $\begin{array}{l}0.411^{*} \\
(0.219)\end{array}$ & $\begin{array}{c}0.394^{*} \\
(0.219)\end{array}$ \\
\hline No. of Observations & 10340 & 10340 & 10340 \\
\hline \multirow[t]{2}{*}{$R^{2}$} & 0.33 & 0.33 & 0.33 \\
\hline & \multicolumn{3}{|c|}{ Panel B: Landed Households } \\
\hline Unmarried at the time of Reform & $\begin{array}{c}0.527^{*} \\
(0.315)\end{array}$ & $\begin{array}{l}0.543^{*} \\
(0.314)\end{array}$ & $\begin{array}{c}0.508 \\
(0.312)\end{array}$ \\
\hline No. of Observations & 6385 & 6385 & 6385 \\
\hline$R^{2}$ & 0.37 & 0.38 & 0.38 \\
\hline
\end{tabular}

Notes: $* * *, * *, *$ denote significance at $1 \%, 5 \%$ and $10 \%$ respectively. Standard errors are clustered at the district level and are reported in parentheses. The dependent variable is the level of education (measured in number of years) completed by the mother. In Panel A, the sample is restricted to rural areas and Hindu households and in Panel B we further restrict the sample to only landed households. Sample of states does not include Jammu \& Kashmir and the North Eastern states. All regressions include district fixed effects and year of marriage fixed effects. Regressions include household weights provided by IHDS. Column 1 presents results with basic controls including age at marriage, if the household is below poverty line (BPL), caste, number of older men and women in the household, year of marriage fixed effects, and district fixed effects. Column 2 adds variables that account for differences between the spouses' economic status at the time of marriage, if the couple belong to the same caste, if land dowry is practiced, and if her husband is her blood relative. In Column 3, we additionally include the total land holding of the woman's marital family. 
Table 4

\section{Intergenerational Impact of HSAA on Children's Education}

\begin{tabular}{|c|c|c|c|}
\hline & $\begin{array}{l}\text { Overall Impact } \\
\text { (1) }\end{array}$ & $\begin{array}{c}\text { Educ }_{\text {father }}<E d u c_{\text {mother }} \\
(2)\end{array}$ & $\begin{array}{c}E_{\text {father }} \geq E d u c_{\text {mother }} \\
(3)\end{array}$ \\
\hline Full Sample & $\begin{array}{r}-\mathbf{0 . 1 0 0} \\
(0.064)\end{array}$ & $\begin{array}{c}-\mathbf{0 . 1 8 6} \\
(0.093)\end{array}$ & $\begin{array}{c}\mathbf{0 . 0 4 2} \\
(0.079)\end{array}$ \\
\hline No. of Observations & 8467 & 2173 & 6294 \\
\hline$R^{2}$ & 0.39 & 0.56 & 0.40 \\
\hline Girls & $\begin{array}{l}-\mathbf{0 . 0 5 1} \\
(0.078)\end{array}$ & $\begin{array}{l}-\mathbf{0 . 0 8 4} \\
(0.124)\end{array}$ & $\begin{array}{c}\mathbf{0 . 0 1 3} \\
(0.098)\end{array}$ \\
\hline No. of Observations & 3918 & 1058 & 2860 \\
\hline$R^{2}$ & 0.48 & 0.63 & 0.50 \\
\hline Boys & $\begin{array}{r}\mathbf{- 0 . 1 2 9} \\
(0.101)\end{array}$ & $\begin{array}{c}-\mathbf{0 . 2 6 7} \\
(0.146)\end{array}$ & $\begin{array}{c}\mathbf{0 . 0 1 8} \\
(0.141)\end{array}$ \\
\hline No. of Observations & 4549 & 1115 & 3434 \\
\hline$R^{2}$ & 0.40 & 0.64 & 0.42 \\
\hline
\end{tabular}

Notes: ${ }^{* * *}, * *, *$ denote significance at $1 \%, 5 \%$ and $10 \%$ respectively. Standard errors are clustered at the district level and are reported in parentheses. The dependent variable is the level of education measured in terms of z-scores. The sample is restricted to rural areas, and Hindu landowning households. Sample of states does not include Jammu \& Kashmir, Kerala and the North Eastern states. Regression includes district fixed effects, year of marriage fixed effects and a full set of controls as described in the empirical strategy section. Regressions include household weights provided by IHDS. Column 1 reports results for all households in our sample, Column 2 reports results for households where the father's education level is less than that of the mother's and Column 3 for those where the father's education is more than or equal to that of the mother's. 
Table 5

\section{Birth Order and Gender Composition of Children Homogenous Households}

\begin{tabular}{|c|c|c|c|c|}
\hline & \multicolumn{2}{|c|}{ All Boys (BB) } & \multicolumn{2}{|c|}{ All Girls (GG) } \\
\hline & $(1)$ & $(2)$ & $(3)$ & $(4)$ \\
\hline Unmarried at the time of the reform & $\begin{array}{c}-0.293^{* *} \\
(0.145)\end{array}$ & $\begin{array}{c}-0.342^{*} \\
(0.179)\end{array}$ & $\begin{array}{c}-0.265^{*} \\
(0.152)\end{array}$ & $\begin{array}{c}-0.372^{* *} \\
(0.179)\end{array}$ \\
\hline Unmarried at the time of the reform ${ }^{*}$ Older $_{b o y}$ & & $\begin{array}{c}0.081 \\
(0.221)\end{array}$ & & \\
\hline Older $_{b o y}$ & & $\begin{array}{c}0.105 \\
(0.195)\end{array}$ & & \\
\hline Unmarried at the time of the reform* ${ }^{*}$ Older $_{g i r l}$ & & & & $\begin{array}{c}-0.224 \\
(0.168)\end{array}$ \\
\hline Older $_{\text {girl }}$ & & & & $\begin{array}{c}-0.063 \\
(0.141)\end{array}$ \\
\hline No. of Observations & 1308 & 1308 & 932 & 932 \\
\hline$R^{2}$ & 0.52 & 0.52 & 0.60 & 0.61 \\
\hline
\end{tabular}

Notes: ***,**,* denote significance at $1 \%, 5 \%$ and $10 \%$ respectively. Standard errors are clustered at the district level and are reported in parentheses. The dependent variable is the level of education measured in terms of z-scores. The sample is restricted to rural areas, and Hindu landowning households. The sample is also restricted to households that have 2 or 3 children between the 5-14 age range. Sample of states does not include Jammu \& Kashmir, Kerala and the North Eastern states. Regression includes district fixed effects, year of marriage fixed effects and a full set of controls as described in the empirical strategy section. Regressions include household weights provided by IHDS. Columns (1) and (3) look at the average intergenerational impact, and Columns (2) and (4) look at the birth order of the child specifically. 
Table 6

\section{Birth Order and Gender Composition of Children Heterogenous Households}

\begin{tabular}{|c|c|c|c|c|}
\hline & \multicolumn{2}{|c|}{ Boy-Girl (BG) } & \multicolumn{2}{|c|}{ Girl-Boy (GB) } \\
\hline & (1) & $(2)$ & $(3)$ & (4) \\
\hline Unmarried at the time of the reform & $\begin{array}{c}-0.698^{* * *} \\
(0.248)\end{array}$ & $\begin{array}{c}-0.741^{* * *} \\
(0.263)\end{array}$ & $\begin{array}{c}-0.279^{*} \\
(0.169)\end{array}$ & $\begin{array}{c}-0.508^{* *} \\
(0.201)\end{array}$ \\
\hline Unmarried at the time of the reform* Older $_{b o y}$ & & $\begin{array}{c}0.085 \\
(0.159)\end{array}$ & & \\
\hline Older $_{b o y}$ & & $\begin{array}{l}-0.018 \\
(0.189)\end{array}$ & & \\
\hline Unmarried at the time of the reform* ${ }^{*}$ Older $_{\text {girl }}$ & & & & $\begin{array}{c}0.375^{* *} \\
(0.186)\end{array}$ \\
\hline Older $_{g i r l}$ & & & & $\begin{array}{c}0.219 \\
(0.201)\end{array}$ \\
\hline No. of Observations & 854 & 854 & 1022 & 1022 \\
\hline$R^{2}$ & 0.69 & 0.69 & 0.55 & 0.55 \\
\hline \multicolumn{5}{|c|}{$\begin{array}{l}\text { Notes: } * * *, * *, * \text { denote significance at } 1 \%, 5 \% \text { and } 10 \% \text { respectively. Standard errors are } \\
\text { clustered at the district level and are reported in parentheses. The dependent variable is the } \\
\text { level of education measured in terms of z-scores. The sample is restricted to rural areas, and } \\
\text { Hindu landowning, } 2 \text { children households. Sample of states does not include Jammu \& Kashmir, } \\
\text { Kerala and the North Eastern states. Regression includes district fixed effects, year of marriage } \\
\text { ixed effects and a full set of controls as described in the empirical strategy section. Regressions } \\
\text { include household weights provided by IHDS. "Boy-Girl" represent households where the boy is } \\
\text { the first born, and "Girl-Boy" households are those where the girl is the first born. Columns (1) } \\
\text { and (3) look at the average intergenerational impact, and Columns (2) and (4) look at the birth } \\
\text { order and gender of the child specifically. }\end{array}$} \\
\hline
\end{tabular}


Table 7

\section{Robustness Checks: Year of Birth \& NSSO data}

\begin{tabular}{|c|c|c|c|}
\hline & (1) & $(2)$ & (3) \\
\hline Reform State*Age $\leq 18$ & $\begin{array}{c}0.720^{* * *} \\
(0.200)\end{array}$ & & \\
\hline Reform State*Age $\leq 10$ & & $\begin{array}{c}0.834^{* * *} \\
(0.16)\end{array}$ & \\
\hline Reform State*Age $>10$ & & $\begin{array}{l}-0.015 \\
(0.14)\end{array}$ & \\
\hline Reform State*Cohort 1 & & & $\begin{array}{c}1.417^{* * *} \\
(0.14)\end{array}$ \\
\hline Reform State*Cohort 2 & & & $\begin{array}{c}0.710^{* * *} \\
(0.18)\end{array}$ \\
\hline Reform State*Cohort 3 & & & $\begin{array}{l}-0.105 \\
(0.12)\end{array}$ \\
\hline Reform State*Cohort 4 & & & $\begin{array}{l}0.073 \\
(0.26)\end{array}$ \\
\hline No. of Observations & 103792 & 103792 & 103792 \\
\hline$R^{2}$ & 0.234 & 0.232 & 0.232 \\
\hline
\end{tabular}

Notes: $* * *, * *, *$ denote significance at $1 \%, 5 \%$ and $10 \%$ respectively. Standard errors are in parenthesis and are clustered at the disitrct level. We use the nationally representative data, NSSO for this analysis. The dependent variable is the level of education (measured in number of years) completed by the mother. The sample is restricted to rural areas and only Hindu households. Sample of states does not include Jammu \& Kashmir and the North Eastern states. All regressions include state fixed effects, cohort fixed effects and state specific cohort trends. Regressions include sample weights as well. 